\title{
The Politics of Toheroa Soup: A Pūkōrero About Whānau and Me
}

\author{
Tiana Pewhairangi Trego-Hall, Lucy Te Awhitu, \\ Alayne Mikahere-Hall
}

\section{Whakarāpopotonga}

Ko te itiiti haeretanga o ngā toheroa, te manga Takutai Penapena Rawa me te awe tau ki tētahi whānau o te Uru ki Raki te tōrangapū o te pakiwaitara waihāro toheroa. Mai noa i te wā o te hekenga mai o ō mātau tūpuna ki Aotearoa, ko te toheroa tētahi o ngā tino kai a tōku whānau. Ka kī au "i" nā te mea kua kore kē mātau e whakaaehia kia haere ki te kohi toheroa mena kāre he pepa whakaae. Ka matapakihia e te pepa nei te āhua o te tuakiri ahurei ahu mai i te toheroa, te moana, te whenua me te whakatureture ngā kaiwhakaawe ka pēhea te māroharoha mai o ngā wheako rangatahi Māori i waenga i ō rātau whānau me ō rātau hapū. Hai whakatairangi ake i ēnei hononga, ka hoatu e au ngā pūkōrero whānau me ngā ariā matapakitanga. He koha iti tēnei pepa mō te whakaputanga motuhake a Ata e whakanui nei i te tekau tau o Waka Oranga: Te Huinga Motuhake o ngā Kaimahi Whakaorahinengaro Māori.

\begin{abstract}
The politics of toheroa soup is a pūkōrero (story) about the slow depletion of the toheroa, the Foreshore Resource Management act and the impacts on one west coast Northland Māori whānau. Toheroa was a main and staple food source for my whānau (family) from the time our tūpuna (ancestors) migrated to Aotearoa. I say "was" because we are no longer allowed to collect the giant surf clam without permits to do so. This paper discusses how whānau and cultural identity is shaped by the toheroa, the moana, the whenua and the legislation that influences how tamariki and rangatahi Māori experiences unfold within their whānau and hapū. To highlight these connections, I present whānau pūkōrero with the inclusion of discussion points. This paper makes a small contribution towards the special volume of Ata celebrating ten years of Waka Oranga: National Collective of Māori Psychotherapy Practitioners (NCMPP).
\end{abstract}

Keywords: Toheroa, surf claims, whānau, moana, whenua, politics.

Much of what I have come to know about toheroa, and the existing situation was told to me by the wāhine in my whānau and more so by Nanny Lucy. I went and interviewed her about whānau recipes for a class assignment and in particular, I wanted to know the secret for

\footnotetext{
Trego-Hall, T. P., Te Awhitu, L., \& Mikahere-Hall, A. (2019). The politics of toheroa soup: A pūkōrero about whānau and me. Ata: Journal of Psychotherapy Aotearoa New Zealand, 23(1), 113-122. https://doi.org/10.9791/ ajpanz.2019.10
} 
making good toheroa soup. The interview was recorded, and as it unfolded, I came to understand so much more about whānau, about whakapapa, the ahi ka and the importance of toheroa to our identity. I have included experiences of three nannies in this article to include Nanny Lucy, Nanny W and Nanny T to help distinguish which nanny I am referring to in my writing. I have included extracts from my interview and pūkōrero with the nannies and whānau and italicised their words within the article. I have drawn on several published articles, particularly Murton (2006) to emphasise our whānau experiences. The cultural realities of rangatahi (young) Māori are hugely influenced by our social circumstances and the people and places we are exposed to. My entire life has been a mix of rural and urban reality with regular and frequent visits to our tūrangawaewae the place we call home. Mead (2003) expresses the concept of tūrangawaewae explaining that it is "... one locality on planet earth where an individual can say 'I belong here. I can stand here without challenge. My ancestors stood here before me. My children will stand tall here...' It is a place associated with the ancestors and is full of history" (p. 43).

From my first recollections, members of Waka Oranga have always called on the support of their respective whānau especially when hui and noho marae happen. My introduction to psychotherapy began when I was still a baby attending my first noho marae when I was 10 months old. As I grew and was old enough to understand, I reflected on my mother's experience and her pūkōrero. My mother explained how affronted she was when some of her Pākehā peers and academic staff questioned the suitability of children attending the noho marae. My mother said, "Sometimes this is what happens when Pākehā enter Māori spaces and places, our belonging becomes contested and our values pushed aside". I have never had the experience of being excluded from the marae. The marae is one place where my belonging and my Māori identity develops. I have come to realise that little is known about the pūkōrero (personal stories) that are important to us as whānau. From the outset Nanny Lucy and I have supported the aspirations of Waka Oranga. This is our opportunity to speak to the aspirations that are important to us as whānau. I present pūkōrero related to the toheroa with each providing insights into issues that are valuable to us as Mãori. What started out as a simple question about a whānau recipe soon turned into the politics of making toheroa soup.

\section{Tiana Pewhairangi’s Pūkōrero}

Since the development of Waka Oranga in 2007, I have quietly listened to the discussions, debates, tensions and agreements that have occurred and the ambitions of a small group of Māori psychotherapists. I was seven years old at that time. I was also seven years old when I collected my first toheroa; this was an exhilarating experience for me. I remember the day clearly, which was overshadowed by unwelcomed interest. On that day, there were four of us, including my four-year-old cousin. We had a permit to gather toheroa for a 70 th birthday celebration. While we were digging, we were being watched by two Pākehā men from the embankment. They stood there watching us the entire time we were there. "What are you looking at" Nanny W shouted. I didn't understand what was going on. "Why are they staring at us mum?" My mother explained why Nanny W was angry. She also explained that it would not be long before a fisheries ranger would turn up; she was right. Nanny W was riled and 
irritated muttering as we collected our toheroa. The imposition, the assumptions, the smugness and a deep sense of injustice; that is what Nanny W was feeling, as they watched us gather our toheroa. A short time later a fisheries office turned up and spoke with the men on the beach before approaching us. Mum assured me we would be okay and encouraged me to carry on. I learnt so much that day. Kidman (2012) investigated the cultural geographies of young Māori stating "identity politics and the politics of belonging are often brought into discussions about the significance of physical territories and "spaces" and their role in the construction of shared cultural meanings" (p.190). As a rangatahi (young person), I rely on whānau to teach and guide me on the things that have cultural relevance. Nanny W's behaviour surprised me and Nanny Lucy's pūkōrero gave me a lot to think about. I became very interested in digging, however this time it was for information about the toheroa and whānau experiences.

\section{Nanny Lucy's Pūkōrero}

This pūkōrero is told from the front deck of Nan's kainga (home) that over-looks Ripirō. She has a clear view of the moana and the beach as it extends to the south. The smell of the moana (ocean) and the crashing of the waves can be heard and seen from her elevated deck. Before she begins her pūkōrero, there is a long silence as she gazes out toward the moana and the whenua. She pauses and is often reflective as her story unfolds; however her pūkōrero begins with a deep sigh and a karakia and ends with karakia. She begins, "korero mai moko" - "Nan can you tell me something about the toheroa?"

The toheroa..., the toheroa came here with our tūpuna, when they arrived here, they brought the toheroa with them. It can be found nowhere else in the world and nobody can say for sure where it came from, but for us it came from Hawaiki-nui, Hawaiki-roa, Hawaiki-pāmamao.

Nan explains that she is ahi kā for the northern end of Ripirō beach. This is a West Coast beach that stretches from the entrance of the Kaipara Harbour to Maunganui Bluff. In her pūkōrero, she talks about her ahi kā appointment by the iwi authority group of Ngāti Whatua. The ahi kā and the ahi-kā-roa are terms that express the importance of keeping the home fires burning by maintaining the intergenerational occupation and kaitiakitanga(guardianship). The ahi kā and ahi-kā-roa are responsibilities to be taken seriously and Nan explains in detail how the fires of occupation have been long held through our whakapapa (genealogy) and whānau. She conveys the stories of tūpuna who have long gone, the size, colour and shape of the toheroa. She goes on to talk about the importance of feeding the people and how the toheroa sustained whānau living locally and neighbouring hapu living further inland. As she spoke, I could hear her memories, I could hear voices of whānau long gone gathering the toheroa, the sun, wind and surf on their faces. I could understand the importance of gathering toheroa, her pūkōrero resonated with me. It has been argued that colloquial speech is representative of meaning, values and social remedies (Trudeau, 2006). I understand better what Osbourne (2001) suggests as the significance of spaces and having them viewed as "storied landscapes". Murton (2006) discusses how the toheroa was once an abundant resource 
for Māori having great cultural significance and the shift from abundance to scarcity. Nan commented,

It was our staple diet, and then they bought in their laws and regulations, they put it in cans and sold it. When we made toheroa soup, we cooked it over the kāuta to feed all the families in Kaihū and to feed the manuhiri, and it cost us nothing.

The early 2oth century was a time of significance when a canneries operation set-up near the west coast settlement of Te Kopuru a short distance from the Ripiroa coastline. Regulation and the issuing of licenses were initiated by canning interests who pushed for exclusive rights once the toheroa was regarded as commercially viable (Murton, 2006; Chief Inspector of Fisheries, 1913a; 1913b). There are accounts of the growing and ongoing concerns raised by Māori and campers concerning the establishment of the canneries, specifically for the sale and exportation of toheroa. Murton (2006) stated, "It is pertinent to point out that these early regulations had little to do with conservation of the resource, but with the protection of specific interests" (p.30). Māori protested when lease rights were granted to the canneries to take large stocks of toheroa which led to insistent over-harvesting (Murton, 2006). As Nan noted,

Local Māori from up and down the beach complained, we the whānau in Kaihū complained, but they did not care they did nothing. The Inspector of Fisheries allowed the cannery to take the toheroa, and they took thousands and thousands of toheroa. They stripped the toheroa beds, and when it was almost all gone, they were gone too.

The shift in Nan's voice was noticeable when she spoke of the laws of the regulations that whānau were forced to abide by. Toheroa has been an important food source for West Coast Māori who have occupied the stretch of coastline known as Ripiroa. The hapu and iwi of this area include Te Uri o Hau (Ngāti Whatua), Te Popoto o Kaipara (Ngāpuhi) and Te Roroa. Nan commented,

The Pākehā made toheroa soup, put it in a can and sold it for a profit. People came from far and wide and pilfered the toheroa they came to make a profit out of the toheroa. They did not want to listen to us, the whānau, the hapu and the people who live here on the whenua, on the moana. They did not care, and they tried to tell us we had no special right to the toheroa it belonged to everyone. When the people went to get toheroa and got caught, they stung us with their fines.

According to Murton (2006) the Marine Department records are full of examples of Māori who resisted the regulations that he referred to as "types of everyday resistance" (p. 34). I could hear both the resistance and concern in Nan's pūkōrero. Murton (2006) in illustrating the points, noted:

Further, the instances in which Mãori were caught and charged with breaches of 
the regulations represent the tip of the iceberg. This became obvious at Kaihu in the mid-1950s: the entire community was involved in an ongoing 'battle' against the regulations through a range of ordinary, everyday practices which very effectively circumvented the regulations, especially with regard to close seasons and quotas. Toheroa were required for food and for special events, and this involved breaking the regulations (p.34).

Nan went on to speak about both Pākehā and Māori from far and wide who descended upon our beaches, hoping to make money for themselves selling and profiting from toheroa.

They put quota systems in place, and we were subjected to the same rules and regulations as every other Māori and Pākehā throughout the country. The people in Kaihū protested, we couldn't feed our old people toheroa, we couldn't feed the families. Now, the toheroa is struggling to survive.

Before my interview with Nanny Lucy I also had the opportunity to interview her sister living in Kaihū who I will refer to as Nanny T. Nanny T was explaining to me the various ways in which toheroa were prepared for eating. She told me that fermented toheroa was a special delicacy of the old people. They enjoyed eating fermented toheroa as it was rich in flavour and it was tender enough for them to chew on. This was really important especially when the elders had no teeth. Murton (2006) discusses how local Māori struggled to claim their rights to toheroa. Common forms of struggle were spurred by whakapapa, affinity and belonging where protest involved what Scott (1985: 29) describes as "the ordinary weapons of relatively powerless groups: foot dragging, dissimulation, false compliance, pilfering, feigned ignorance, slander, arson, sabotage and so on” (p. 29). As Nan noted,

They tried to blame us, they told everyone we were to blame, your tupuna gave evidence, told them he could remember nine generations back from him. That was a long time ago and the toheroa was always plentiful to all those generations... Moko, remember this; your tupuna, Paiwiko fought for the people in Kaihū.

Murton (2006) explains how Māori were actively involved with politicisation in "both direct and indirect ways in lobbying for their rights to take toheroa. However, they were a relatively insignificant voice to Pākehā politicians and policy makers beholden to an electorate and business interests (p. 34). My great grandfather Paiwiko and my tupuna worked hard to protect the interest of our hapū and tangata whenua. My tupuna (Parore, 1933; Te Rore, 1939; Anania, 1941|1948) lobbied against the Fisheries Acts since their inception. Like many whānau, we too protested and joined the hikoi (march) that mobilised whānau, hapū and iwi throughout Aotearoa to reject the Foreshore and Seabed Act 2004. This was a significant event in New Zealand history where Kidman (2012) states "politics would change in the aftermath of the foreshore and seabed legislation as new political groups began to emerge from urban and tribal Māori communities” (p.190). The challenge is left for us the young rangatahi Māori to carry, as Nan encouraged, 
But we are still here and even our little ones in the schools up here they are learning about the toheroa. The people [Māori] are doing their own conservation work and they are teaching the little ones. They are growing pingao up and down the beach, toheroa need the pingao plant and it needs fresh clean water.

Nan wonders with concern about the mantel of ahi-ka. "Who will pick this up when I am gone?" She has gone to lengths to provide examples of how both her and papa Joe saw themselves as kaitiaki of the moana. Papa Joe is no longer with us, he was a gentle and kind man who never complained. Papa Joe loved the moana and he was with me the day I caught my first fish off the rocks with a make-shift fishing line.

On the contrary Nanny, Lucy never minced her words and if she believed there was a cause worth fighting, she would walk her talk. Nanny Lucy and Papa Joe were both active in the seabed and foreshore hikoi protesting against legislative change. I can make a claim for walking a short distance. My mother has told me that most of my loud protests were as a consequence of having to walk and an insistence to be pushed along in my younger cousin's stroller. She assured me that every step counted.

\section{Aunty Nellie's Pūkōrero}

Aunty began by saying "Now listen Tiana, there is something else I want to tell you about the toheroa". Aunty Nellie was present when I was interviewing Nanny Lucy and her contributions have provided me with more insights.

When I was hapu (pregnant) with my children my uncles and the men would go out and dig for toheroa. They would make sure that you had something special, not just everyday kai (food)but the toheroa. The toheroa is special and because we understand how special it is, it was not taken for granted. The uncles did this for their mother, their sisters, their wives and their nieces. My older male cousins did this too, a lot of the younger ones don't know this.

I found the pūkōrero fascinating as it gave me greater awareness about the relationship between the toheroa and the socio-cultural norms of my whānau. Whānau were connected to the toheroa as an investment in whakapapa, as an investment in future tamariki (children) and mokopuna (grandchildren). Aunty continued,

Today, we can't teach them this because now you need permits to get toheroa. In those days, the men wanted to make sure that the pregnant wāhine and her unborn baby was getting the best of what they could give them. Giving toheroa to hapu mama was their expression of aroha (love-endearment).

I did not interview any tāne (men) for their pūkōrero which was mostly due to time constraints and the practicalities of approaching whānau on the day we travelled home. However, my aunt's pūkōrero spoke to the fondness and love our men felt for their wāhine and for the unborn tamaiti (child). I imagined that these acts of aroha, giving toheroa helped 
to foster the emotional bonds that whānau have for each other and the attachment to the takutai moana (seabed \& foreshore). The pūkōrero were deepening my own connections and aroha for the people and the places that sustained and nurtured them. As Nan commented,

The toheroa is spiritually connected to the moana, to the whenua, to the people and the hapū (extended family) and the hapū māmā (pregnant mother). Everyone knew when they came to our marae, they could expect to get toheroa served up on our tables.

The spiritual aspects are central again to the cultural beliefs and everything connected to the environment. I have heard, I have felt, and I have read many accounts of the intimate spiritual relationship Māori have with their immediate environment. Staying with Murton's (2006) description, he stated,

The natural world was indivisible, one with the spiritual world, with all things having life force (mauri) and spirit (wairua). Families such as those living near the North Kaipara beach, had an obligation to care for resources such as toheroa, both physically and spiritually (p. 35).

The Crown's authority asserts their position of what is deemed kaitiakitanga and this is not invested in tangata whenua who have held the ahi-ka-roa for generations. According to the Chief Inspector of Fisheries (1939) the toheroa were "national possessions that belonged to everyone, and just because some families live near them, he did not think they should be privileged” (Cited in Murton, 2006, p. 31). Local Māori interests lay buried in the sand, dwindling like the toheroa. Perhaps this is why the toheroa are leaving us? This also raises the question about how Māori psychotherapy attends to Māori grievances and our whānau sadness, the embodied and deeply felt spiritual bond we have for the toheroa? Nan observed,

To offer manuhiri toheroa made us feel happy, it was a great source of pride. We did not feel good if we could not give our manuhiri toheroa. It was from the toheroa that the people, the hapu gained its' source of mana. The toheroa was a big part about who we are as people.

Reflecting back on my first experience of gathering toheroa, I remembered my mother's relief once we had delivered on our promise to collect the toheroa for the 7oth birthday celebrations. What joy this brought to everyone. According to Murton (2006) "Toheroa also were prestigious seafood (kai moana), absolutely necessary for hui (meetings) and tangi (funerals) for the coastal peoples" (p. 26). The birthday celebration went ahead and although the process of gathering the toheroa was stilted, we knew as a whānau, that our mana remained unbroken that day. Aunty Nellie encouraged me,

So, I hope you understand the connection and why the gift of toheroa to a hapu mama and an unborn mokopuna was so special. I hope someday when your time comes someone will give you toheroa too. 
Murton (2006) states "Part of the identity of Mãori living along the Kaihū and Wairoa [Northern] river valleys was bound up with toheroa. The shellfish was not only an important food source but was symbolic of their existence" (p. 35).

\section{Discussion}

The whānau pūkorero were conveying more than just a taste for toheroa they were revealing a dependency on a food source where existence, identity and belonging were intimately tied to the toheroa. The moana, the foreshore and the whenua have all been contested environments threatening whānau existence and politicising the place we call home. Places, according to Schnell and Mishal (2008) act as an "incubator" for cultural and identity formation. They suggest that sociospatial expression influences identity construction (Kidman, 2012). I reflected back to when I was seven feeling thrilled with myself when I found my first toheroa. I was oblivious to the past. I remember my mother's disappointment and sadness when she explained that she could not give me the experiences she had grown up with. My mother said "There were so many of us, my Nan had so many children and mokopuna. You could not shop for that many people there was no money for that. We were reliant on the kaimoana (seafood) to keep us going and our gardens." She explained the tikanga was to never take any more than was needed and never to waste the kai (food), she said this was unheard of. I remember the Pākehā men watching us from the embankment, the Fisheries officer arriving and how they were to us, self-righteously determining our fate. According to Murton (2006) "The local Pākehā opinion leaders were certain that many of the toheroa taken were being sold illegally by Māori , and that these 'raids' were the primary cause of depletion (p. 28).” Looking back, I understand better now why Nanny W was feeling so angry that day. Like Nanny Lucy said they blamed us they blamed the Māori and the events that day on the beach with Nanny W were re-enactments of the past. Nanny W taught me how to gather toheroa and Nanny T had taught me about the food adored by our kuia-korua (elderly men and women). Together Nanny Lucy's and Aunty Nellie's pūkorero taught me about customary title, identity, belonging and a shared symbiosis between people and their environment. Importantly, te kai o te Rangatira - the food of chiefs.

\section{Conclusion}

This paper offers some insights into one intergenerational whānau experiences and the importance of toheroa to us. I have a much greater appreciation, understanding and sense of responsibility for this taonga (treasure) we call toheroa. I hope you do too. All whānau Māori will have their special pūkōrero to tell, this is just one of ours. I am left wondering about the importance of Waka Oranga and the development of therapies for Māori and can appreciate why universal assumptions do not always fit well for us. Today, the toheroa beds are struggling to recover despite best efforts to do so. The toheroa are dependent on us to ensure their survival. In retrospect the class assignment ignited something much deeper. I took for granted the valuable food source that kaimoana and in particular the toheroa meant to me and my whānau. My identity has been shaped by the toheroa, the moana, the whenua, and the legislation that determines outcomes for rangatahi Māori. Eating toheroa 
has deepened and sealed my connection to my tūpuna and whānau like never before. I hope someday when I have children, my children's children can enjoy the taste of toheroa and my mokopuna can hear the whānau pūkōrero from me.

In 2007 , I gathered and ate toheroa for the first time. I was eating kai that my tūpuna from Hawaiki-nui, Hawaiki-roa, Hawaiki-pāmamao had eaten and brought with them to Aotearoa.

\section{References:}

Anania (1941). To P.K. Paikea MP, October 12. Marine Department, M1 2/12/99, Archives New Zealand, Wellington.

Anania (1948). To Acting Māori Minister, November 18. Marine Department, M1 2/12/574, Archives New Zealand, Wellington.

Antonsich, M. (2010). Searching for belonging - An analytical framework. Geography Compass, $4(6), 644-659$.

Chief Inspector of Fisheries, (1913a). To Secretary, Marine Department, April 19. Marine Department, M1 2/12/9, Archives New Zealand Wellington.

Chief Inspector of Fisheries, (1913b). To Secretary, Marine Department, August 7. Marine Department, M1 2/12/9, Archives New Zealand Wellington.

Kidman, J. (2012). The land remains: Māori youth and the politics of belonging. AlterNative: An International Journal of Indigenous Peoples, 8(2), 189-202.

Mead, H. M. (2003). Tikanga Mäori: Living by Mäori values. Wellington, New Zealand: Huia Publishers.

Ministry of Justice. (2004, December). The Foreshore and Seabed Act 2004. [Brochure]. Wellington, New Zealand: New Zealand Government publication.

Murton, B. (2006). 'Toheroa Wars': Cultural politics and everyday resistance on a northern New Zealand beach. New Zealand Geographer, 62(1), 25-38.

Parore (1933). To Rt. Hon. J. G. Coates, February 13. Marine Department, M1 2/12/9, Archives New Zealand, Wellington.

Ross, P. M., Beentjes, M. P., Cope, J., de Lange, W. P., McFadgen, B. G., Redfearn, P., ... \& Te Tuhi, J. (2018). The biology, ecology and history of toheroa (Paphies ventricosa): a review of scientific, local and customary knowledge. New Zealand journal of marine and freshwater research, 52(2), 196-231.

Schnell, I., \& Mishal, S. (2008). Place as a source of identity in colonising societies. Geographical Review, 98(2), 242-259.

Te Rore (1939). To Prime Minister, November 10. Māori Affairs, MA 43/1/3, Archives New Zealand, Wellington. 


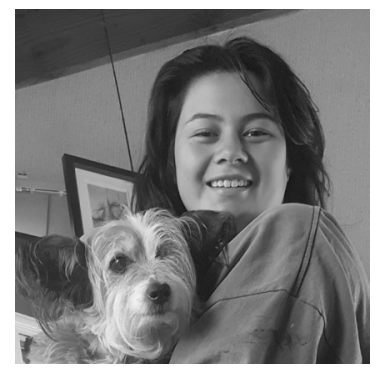

Tiana Pewhairangi Trego-Hall has kinship affiliations to Ngāti Whatua, Te Rarawa, Tainui and Mangaia in the Cook Islands. She is a first year university student studying law and media. Tiana hopes to one day work as a Human Rights advocate utilising media as a vehicle to highlight political, social, cultural injustices and Indigenous achievements. She also has a keen interest in reducing the impacts of global warming particularly in the South Pacific region. Tiana is the recipient of a Te Rarawa education scholarship and as a year 11 student, she undertook her first voluntary experience in Vanuatu.

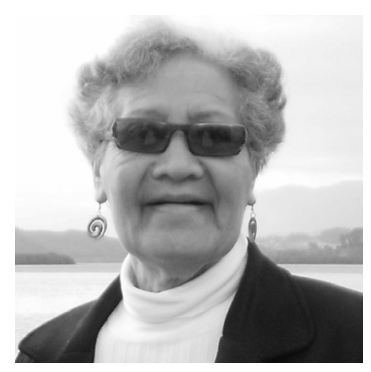

Lucy Te Awhitu (Nanny Lucy) is a descendant mokopuna of the Ngāti Whatua hapū , Te Taou and Te Uri o Hau. She also descends from the hapū Ngāti Kaha of the Te Rarawa people in the Hokianga region of Northland. She was born and raised on Maunganui Bluff and the small settlement of Kaihu. In the 1980's Nanny Lucy and Papa Joe were appointed ahi-kā and kaitiaki ārahi (guardian custodians) by Te Rūnānga o Ngāti Whatua. Nanny Lucy continues to live on Maunganui Bluff over-looking the moana Ripiroa. Papa Joe is a descendant mokopuna of the Tūwharetoa and Tainui people. E Pā, kua wehe atu rā ki te okiokinga hoki atu ki te kainga o te Kaihanga - moe mai rā. You have departed to return home to your creator to rest eternally Pā.

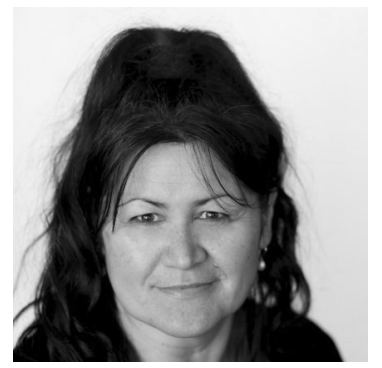

Alayne Mikahere-Hall is kinship affiliated with Ngāti Whatua, Te Rarawa and Tainui. Alayne is a post-doctoral research fellow with Taupua Waiora Research Centre, Auckland University of Technology. She is the lead investigator on the Tūhono Māori research project, funded by the Health Research Council of New Zealand. Tūhono Māori is an investigation into a Māori understanding of secure attachment. Alayne engages with Indigenous methodologies and Kaupapa Māori methods and theory. She has an interest in developing evidence-based Māori and Indigenous therapeutic interventions to develop theories concerning complex trauma. Alayne is also an investigator on the E Tū Wāhine, E Tū Whānau study, aimed at reducing the harmful effects of violence against women and families and to break cycles of complex whakapapa trauma (inter-generational family trauma). She is a current member of the Health Quality and Safety Commission Child Youth Mortality Review Committee and Nga Pou Arawhenua Mortality Review Committee. Alayne is a Registered Psychotherapist, a member of the New Zealand Association of Psychotherapists (NZAP) and a founding member of Waka Oranga - National Collective of Māori Psychotherapy Practitioners (NCMPP).Contact details: alhall@aut.ac.nz. 